\title{
Characterization of an Acetate-Decarboxylating, Non-Hydrogen-Oxidizing Methane Bacterium
}

\author{
Alexander J. B. Zehnder ${ }^{1}$, Beat A. Huser ${ }^{2}$, Thomas D. Brock ${ }^{1}$, and Karl Wuhrmann ${ }^{2 *}$ \\ 1 Department of Bacteriology, University of Wisconsin-Madison, Madison, Wisconsin 53706, USA \\ 2 Swiss Federal Institute of Technology, Zürich and Federal Institute for Water Resources and Water Pollution Control, Überlandstrasse 133, \\ CH-8600 Dübendorf, Switzerland
}

\begin{abstract}
A methanogenic bacterium, commonly seen in digested sludge and referred to as the "fat rod" or Methanobacterium soehngenii, has been enriched to a monoculture and is characterized. Cells are gramnegative, non-motile and appear as straight rods with flat ends. They form filaments which can grow to great lengths. The structure of the outer cell envelop is similar to Methanospirillum hungatii. The organism grows on a mineral salt medium with acetate as the only organic component. Acetate is the energy source, and methane is formed exclusively from the methyl group. Acetate and carbon dioxide act as sole carbon source and are assimilated in a molar ratio of about 1.9:1. The reducing equivalents necessary to build biomass from these two precursors are obtained from the total oxidation of some acetate. Hydrogen is not used for methane formation and is not needed for growth. Formate is cleaved into hydrogen and carbon dioxide. Coenzyme $M$ was found to be present at levels of $0.35 \mathrm{nmol}$ per $\mathrm{mg}$ of dry cells and $\mathrm{F}_{420}$ amounted to $0.55 \mu \mathrm{g}$ per $\mathrm{mg}$ protein. The mean generation time was 9 days at $33^{\circ} \mathrm{C}$.
\end{abstract}

Key words: Methane bacterium - Electronmicroscopy - Acetate decarboxylation - Formate decarboxylation - Acetate assimilation - $\mathrm{CO}_{2}$ assimilation Growth yield - Coenzyme $\mathrm{M}-\mathrm{F}_{420}$.

Hoppe-Seyler (1876) described an experiment with sewage sludge in which methane was obtained from calcium acetate. The same author reported in 1887 that acetate is cleaved into equal amounts of methane and

* To whom offprint requests should be sent carbon dioxide when incubated anaerobically in water containing 10\% mud. During his thesis work, Söhngen (1910) observed the same process, and like HoppeSeyler he could not detect bacteria in the liquid above the precipitate. But by analyzing the sediment in the tubes, he found two distinct gram-negative organisms, a sarcina and a rod which could form long filaments often associated in bundles. This latter methane bacterium has not been identified with certainty nor redescribed for three decades although Groenewege (1920) and Buswell and Neave (1930) mentioned observing a rod-shaped bacterium which differed only slightly from the organism described by Söhngen. The sarcina, however, has been seen both in acetate enrichments and in sewage sludge by several investigators (Groenewege, 1920; Buswell and Neave, 1930; Smit, 1930). In 1936, Barker had again enrichment cultures of both organisms and named the sarcina Methanosarcina methanica and the filamentous organism Methanobacterium soehngenii. In 1947, Schnellen isolated a pure culture of the sarcina which he subsequently called Methanosarcina barkeri. Sarcinas of the barkeri-type have been reisolated several times (Stadtman and Barker, 1951; Zhilina, 1971; Zeikus and Winfrey, 1976; Mah et al., 1978). They remained the only pure cultures of methanogenic bacteria able to utilize and grow on acetate alone (Smith and Mah, 1978). Although the filamentous organism, known also as the "fat rod", was seen by many investigators in enrichments from digested sludge with acetate as the only organic substrate (Mylroie and Hungate, 1954; Pretorius, 1972; Ferry and Wolfe, 1976; van den Berg et al., 1976), attempts to isolate this bacterium were not successful.

We characterize here such a filamentous methane bacterium which utilizes predominantly acetate as methanogenic substrate and has features somewhat similar to Methanobacterium soehngenii (Bryant, 1974) and the "fat rod". 


\section{Materials and Methods}

\section{Source of the Organism}

Samples of digested sludge from the sewage treatment plant in Opfikon near Zürich, Switzerland, and from the Madison Metropolitan sewage treatment plant (Wisconsin, USA) were used for enrichment cultures. In the following, only the characteristics of the Opfikon strain are described.

\section{Media and Cultivation}

To prepare sterile media for subculture and maintenance of the organism, the following stock solutions were used (chemicals in grams per liter of distilled water): (A) $\mathrm{KH}_{2} \mathrm{PO}_{4}, 27.2$; (B) $\mathrm{Na}_{2} \mathrm{HPO}_{4}$, 28.4; (C, mineral salt solution) $\mathrm{NH}_{4} \mathrm{Cl}, 24 ; \mathrm{NaCl}, 24 ; \mathrm{CaCl}_{2} \cdot 2 \mathrm{H}_{2} \mathrm{O}$, 8.8; and $\mathrm{MgCl}_{2} \cdot 6 \mathrm{H}_{2} \mathrm{O}, 8$; (D) $\mathrm{NaHCO}_{3}, 80$; (E, trace metal solution) $\mathrm{FeCl}_{2} \cdot 4 \mathrm{H}_{2} \mathrm{O}, 2 ; \mathrm{H}_{3} \mathrm{BO}_{3}, 0.05 ; \mathrm{ZnCl}_{2}, 0.05 ; \mathrm{CuCl}_{2}, 0.03$; $\mathrm{MnCl}_{2} \cdot 4 \mathrm{H}_{2} \mathrm{O}, 0.5 ;\left(\mathrm{NH}_{4}\right)_{6} \mathrm{Mo}_{7} \mathrm{O}_{24} \cdot 4 \mathrm{H}_{2} \mathrm{O}, 0.05 ; \mathrm{AlCl}_{3}, 0.05$; $\mathrm{CoCl}_{2} \cdot 6 \mathrm{H}_{2} \mathrm{O}, 0.05 ; \mathrm{NiCl}_{2}, 0.05$; ethylenediaminetetraacetate, 0.5 , and $1 \mathrm{ml}$ of concentrated $\mathrm{HCl} ;(\mathrm{F}) \mathrm{Na}_{2} \mathrm{SeO}_{3}, 0.1 ;(\mathrm{G})$ vitamin mixture according to Wolin et al. (1963); (H) $\mathrm{Na}_{2} \mathrm{~S} \cdot 9 \mathrm{H}_{2} \mathrm{O}, 240.2$; (I) resazurin 0.5 . The medium had the following composition: $15 \mathrm{ml}$ of solution $\mathrm{A}, 15 \mathrm{ml}$ of solution $\mathrm{B}, 1 \mathrm{ml}$ of solution I and the desired amount of sodium acetate were made up with distilled water to $900 \mathrm{ml}$ and sterilized at $121^{\circ} \mathrm{C}$ under an atmosphere of $85 \% \mathrm{~N}_{2}$ and $15 \%$ $\mathrm{CO}_{2} ; 1 \mathrm{ml}$ of trace metal solution $\mathrm{E}, 1 \mathrm{ml}$ of solution $\mathrm{F}, 1 \mathrm{ml}$ of vitamin solution $\mathrm{G}$, and $12.5 \mathrm{ml}$ of solution $\mathrm{C}$ in $35.5 \mathrm{ml}$ of distilled water were added aseptically to the autoclaved medium by using a Millex microsyringe filter holder with a $0.2-\mu \mathrm{m}$ membrane filter (Millipore Corp., Bedford, Mass.). Next, $0.03 \mathrm{~g} \mathrm{Na}_{2} \mathrm{~S}_{2} \mathrm{O}_{2}$ and $1.5 \mathrm{ml}$ of sulfide solution $\mathrm{H}$ in $40 \mathrm{ml}$ of solution $\mathrm{D}$ were added in the same way. Immediately after, the medium was gassed again with an oxygen-free gas mixture of $85 \% \mathrm{~N}_{2}$ and $15 \% \mathrm{CO}_{2}$ to remove all possible traces of oxygen. Cells were routinely cultivated in $150-\mathrm{ml}$ serum vials closed with black lip rubber stoppers and sealed with an aluminum seal (Balch and Wolfe, 1976)*:The amount of medium was normally $50 \mathrm{ml}$. Experiments were performed (if not otherwise specified) in $35-\mathrm{ml}$ sealed serum vials containing $20 \mathrm{ml}$ of medium. The gas phase was brought to $152 \mathrm{kN} / \mathrm{m}^{2}$ (1.5 atm). When necessary, it was replaced in order to maintain a constant $\mathrm{pH}$ of 7.0 (Zehnder and Wuhrmann, 1977).

\section{Enrichment and Isolation}

The initial enrichment was performed in a $1.5-1$ fermenter with digested sludge from Opfikon. The anaerobic fermenter was continuously fed with the above medium to obtain a mean retention time of 15 days at $33^{\circ} \mathrm{C}$. After one year of continuous cultivation, samples of the fermenter culture were diluted according to the most probable number technique (MPN) and incubated at $37^{\circ} \mathrm{C}$. The highest dilution showing growth was further diluted. From this second series the most diluted and growing culture was used for this study. in addition to microscopical examination, isolates were checked for purity by adding to the above medium either Difco Thioglycollate Broth or yeast extract, hydrogen, sulfate and glucose. Absence of turbidity in both media were taken as criteria of purity. Cultures were routinely checked microscopically and by transfers into these two media.

\section{Analytic Procedures}

Methane and acetate were detected with a gas chromatograph (model 419, Packard lnstrument Co., Inc.) equipped with a Poropak QS $(80 / 100$ mesh) column connected to a flame ionization detector (FID). Column temperature isothermic at $180^{\prime \prime} \mathrm{C}$, carricr gas nitrogen, flow rate $45 \mathrm{ml} / \mathrm{min}$. The same settings were used for both methane and acetate.

\section{Experiments with Radiotracer}

Experiments with radiotracers were performed at $35^{\circ} \mathrm{C}$ in $35-\mathrm{ml}$ serum vials as described above. Depending on the experiment, the headspace was either composed of $85 \% \mathrm{~N}_{2}$ and $15 \% \mathrm{CO}_{2}$ or $80 \% \mathrm{H}_{2}$ and $20 \% \mathrm{CO}_{2}$. Growth and metabolism in experiments with radioactive substrates were stopped by injecting concentrated $\mathrm{HCl}$ into the serum vials to obtain a final $\mathrm{pH}$ of 2.0 . Then, the following fractionation procedure was used: $1 \mathrm{ml}$ gas from the headspace was removed with a Pressure Lok syringe (Precision Sampling Co., Baton Rouge, LA) and analyzed for ${ }^{14} \mathrm{CH}_{4}$ by the liquid scintillation method (Zehnder et al., 1979). For this purpose, a septum was placed between scintillation vial and screw cap. In addition, a small hole was drilled into the cap for entry of a hypodermic needle. To determine ${ }^{14} \mathrm{CO}_{2}$, another $1 \mathrm{ml}$ gas sample was taken and injected into a scintillation vial containing $2 \mathrm{ml}$ phenethylamine (scintillation grade) and $2 \mathrm{ml}$ methanol. These vials were modified in the same way as for ${ }^{14} \mathrm{CH}_{4}$ determination. Subsequently, the scintillation vial was vigorously shaken to absorb all $\mathrm{CO}_{2}$. The septum was removed and the liquid sparged with air for $5 \mathrm{~min}$ to eliminate the methane remaining in the liquid. Then the scintillation vial received $10 \mathrm{ml}$ of a toluenefluor mixture containing $0.375 \mathrm{~g}$ of 2,5-diphenyloxazole (PPO, Beckman Instruments, Inc., Fullerton Cal.) and $0.1 \mathrm{~g}$ of $1,4-\mathrm{bis}-[2(4-$ methyl-5-phenyloxazolyl)]benzene (dimethyl-POPOP, Packard Instrument Co., Inc., Downers Grove, Ill.) per $1,000 \mathrm{ml}$ of toluene. In order to determine the total ${ }^{14} \mathrm{CO}_{2}$, the amount of ${ }^{14} \mathrm{CO}_{2}$ measured was corrected for the ${ }^{14} \mathrm{CO}_{2}$ dissolved in the acid medium. To measure the radioactivity incorporated into particulate matter (biomass), $10 \mathrm{ml}$ of the acidified culture suspension was filtered through a $0.45-\mu \mathrm{m}$ membrane filter (Gelman Instrument Co., Ann Arbor, Mich.; type, metricel GN-6) and the filter washed with $0.85 \% \mathrm{NaCl}$. After drying, the filters were exposed to $\mathrm{HCl}$ vapors for $20 \mathrm{~min}$, and were then digested with $1 \mathrm{ml} \mathrm{NCS} \mathrm{(Amersham,} \mathrm{Arlington} \mathrm{Heights,}$ III.) for another $20 \mathrm{~min}$ at $60^{\circ} \mathrm{C}$. Prior to the addition of $10 \mathrm{ml}$ Aquasol (New England Nuclear Corp., Boston, Mass.) the NCS was neutralized with $50 \mu \mathrm{l}$ glacial acetic acid. $1 \mathrm{ml}$ of the filtrate, which still contained the labeled substrates other than $\mathrm{CO}_{2}$, was sparged with air for $5 \mathrm{~min}$ and subsequently mixed with $10 \mathrm{ml}$ Aquasol. The radioactivity was counted with a Tri-Carb 3375 liquid scintillation spectrometer (Packard Instrument Co., Inc.) with the window set at 40 to 1000 and the gain at $12 \%$. Quench corrections were made by the channels-ratio method.

\section{Determination of Coenzyme $M$}

The concentration of coenzyme $\mathrm{M}$ in our organism was measured by using Methanobacterium ruminantium strain M1. This organism shows a specific requirement for HS-CoM. The assay were done following the procedure described by Balch and Wolfe (1976).

\section{Determination of $F_{420}$}

The concentration of $F_{420}$ was measured spectrophotometrically with an " $F_{420}$-dependent-NADP-linked-hydrogenase assay" (Tzeng et al., 1975). The cell extract for use in the hydrogenase catalyzed reduction of $F_{420}$ was prepared as described by Gunsalus and Wolfe (1977). Pure $\mathrm{F}_{\mathbf{4 2 0}}$ from Methanobacterium strain M.O.H. (provided by L. D. Eirich) was used as standard. Protein was assayed following the method of Lowry et al. (1951).

\section{Electron Microscopy}

For scanning electron microscopy, the cells were fixed in a $0.05-\mathrm{M}$ phosphate buffer ( $\mathrm{pH} 7.2$ ) containing $2 \%$ glutaraldehyde and $0.1 \%$ ruthenium red. The organisms were dehydrated through a graded series of water-ethanol mixtures. The ethanol was gradually replaced by the nonpolar solvent amyl acetate. The cells were dried following the method of critical point drying (Horridge and Tamm, 1969) and 
subsequently coated with gold. The scanning electron micrograph was taken by Mrs. D. Metzger at the Botanical Institute of the University of Zürich. For negative staining, cells were trcated with a $2 \%$ aqueous solution of phosphotungstic acid at pH 6.8 .

For thin sectioning, cells were washed and centrifuged. The pellet was suspended in a fixative that contained $2.5 \%$ glutaraldehyde in $0.2 \mathrm{M}$ cacodylate buffer ( $\mathrm{pH} 7.3$ ). After incubation for $1 \mathrm{~h}$ at room temperature, the cells were washed in $0.07 \mathrm{M}$ cacodylate buffer $(\mathrm{pH} 7.3)$. The pellet was suspended in $1.5 \%$ purified agar (Difco) at $50^{\circ} \mathrm{C}$. The cooled agar was cut into small cubes and fixed for $1 \mathrm{~h}$ in the following solution: $4 \mathrm{ml}$ of a $0.2 \mathrm{M}$ cacodylate buffer ( $\mathrm{pH} 7.3$ ) mixed with $2 \mathrm{ml} \mathrm{of} 5 \% \mathrm{OsO}_{4}$ and $6 \mathrm{ml}$ of distilled water. The agar cubes were washed with cacodylate buffer, dehydrated in graded ethanol and placed in propylene oxide. Subsequently they were filtered and embedded in Spurrs medium (Spurr, 1969). Thin sections were stained by $1 \%$ uranyl acetate and then by lead citrate as described by Reynolds (1963).

\section{Chemicals and Radioisotopes}

Sodium selenite was obtained from K \& $\mathrm{K}$ Laboratories, Inc., Plainview, New York. Coenzyme $M$ as mercaptoethane sulfonic acid sodium salt was purchased from Pierce Chemical Co., Rockford, Ill. The following radiochemicals were obtained from New England Nuclear Corp., Boston, Mass.: sodium $\left[{ }^{14} \mathrm{C}\right]$ bicarbonate $(50 \mathrm{mCi} / \mathrm{mmol})$, sodium $\left[1-{ }^{14} \mathrm{C}\right]$ acetate $(2.5 \mathrm{mCi} / \mathrm{mmol})$, sodium $[2-$ $\left.{ }^{14} \mathrm{C}\right]$ acetate $(2 \mathrm{mCi} / \mathrm{mmol}),\left[{ }^{14} \mathrm{C}\right]$ methanol $(0.85 \mathrm{mCi} / \mathrm{mmol})$ and sodium $\left[{ }^{14} \mathrm{C}\right]$ formate $(4 \mathrm{mCi} / \mathrm{mmol})$.

\section{Results}

\section{Enrichment and Isolation}

The initial enrichments were performed under higly selective conditions at $33^{\circ} \mathrm{C}$ in a continuous culture system with a mean residence time of 15 days (dilution rate $=0.066 \mathrm{~d}^{-1}$ ). A decrease of the residence time to 12 days for 6 volumetric displacements did not affect the decarboxylating activity of the system, whereas a further lowering to 9 days produced a clearly recognizable washout effect. We estimate, therefore, a mean generation time of approx. 9 days for the acetatecleaving, methanogenic population in our fermenter. The half saturation constant $\left(K_{\mathrm{s}}\right)$ for acetate, measured in the course of the continuous cultivation, remained unchanged at $0.46 \pm 0.10 \mathrm{mM}$. During the enrichment process, a filamentous gram-negative organism became dominant. Its morphology was similar to Methanobacterium soehngenii (Barker, 1936) or to the "fat rod" seen in many acetate enrichments by different investigators (e.g. Mylroie and Hungate, 1954; Pretorius, 1972; Ferry and Wolfe, 1976; van den Berg et al., 1976). After one year of continuous cultivation only few contaminants could be observed under the microscope. At this stage, theoretically only 50 parts per billion of the original sludge still remained in the reactor. Samples from the one-year enrichment were diluted following the most probable number technique (MPN). After 3-4 months, the $10^{-6}$ dilution showed the formation of white and fuzzy flocks with a diameter of $1-2 \mathrm{~mm}$, paralleling the build-up of methane in the headspace. Longer incubations at $37^{\circ} \mathrm{C}$ did not result in growth or methane formation in dilutions higher than $10^{-6}$. Under the microscope only this very distinct type of filamentous bacterium was observed. Nevertheless, a further dilution series was made from a $10^{-6}$ vial. After another 4 months, again the $10^{-6}$ vials were the highest dilutions showing growth and methane formation. The second $10^{-6}$ culture was tested with the complex media but no contaminants grew up, even after 4 weeks of incubation. On agar roll tubes we were never able to obtain entirely contamination-free colonies.

At every second transfer, $4.5 \mathrm{ml}$ of the culture to be used as inoculum was injected into an anaerobic tube which contained $1 / 2 \mathrm{ml}$ of a concentrated thioglycollate or yeast extract medium. After 4 transfers some test tubes indicated contaminants but the number of contaminants was very low and remained at that level during several transfers. Because of the very slow growth rate of our organism, it is very difficult to grow large batches of cells without obtaining occasional contaminants, but it seems unlikely that these contaminants, probably introduced from the aerobic laboratory environment, would be methanogens. In fact, controls with $\mathrm{H}_{2} / \mathrm{CO}_{2}=80 / 20$ in the headspace showed no methane production. In the presence of $100 \mathrm{mg} / \mathrm{l}$ vancomycin, a concentration which is just not inhibitory for the acetate organism, all contamination tests remained negative even after several transfers. In the following, this filamentous organism able to form methane from acetate will simply be called "acetate organism".

\section{Morphology}

The "acetate organism" forms very long filaments which appear to be quite flexible (Fig. 1a). The Gram stain is negative. These filaments are commonly composed of several hundred single cells, and they can grow to considerable length. Intensive shaking breaks these threads into small pieces of single cells. Figure $1 \mathrm{~b}$ and $\mathrm{c}$ show the characteristic flat ends of these cells. In the scanning electron micrograph, the septa between the individual cells can be seen as bulges. The mean dimensions of a single cell are $0.8 \times 3.3 \mu \mathrm{m}$. The arrangement of the cells in the filaments is shown in Fig. $2 a$ and $b$. Phosphotungstic acid stained filaments (Fig. 2b, d), and the thin cross- (Fig. 2c) and longitudinal sections (Fig. 2a-i) indicate the existence of a thin, though rigid cell wall and a double membrane enveloping the cytoplasm. The double layer structure of appr. $16 \mathrm{~nm}$ thickness of this cytoplasm membrane is most clearly indicated in Fig. $2 \mathrm{f}$ and i. It seems that the cytoplasm has shrunk in some of our preparations since this electron-dense material is separated from the wall in some cuts (e.g. Fig. $2 \mathrm{f}$ ). 

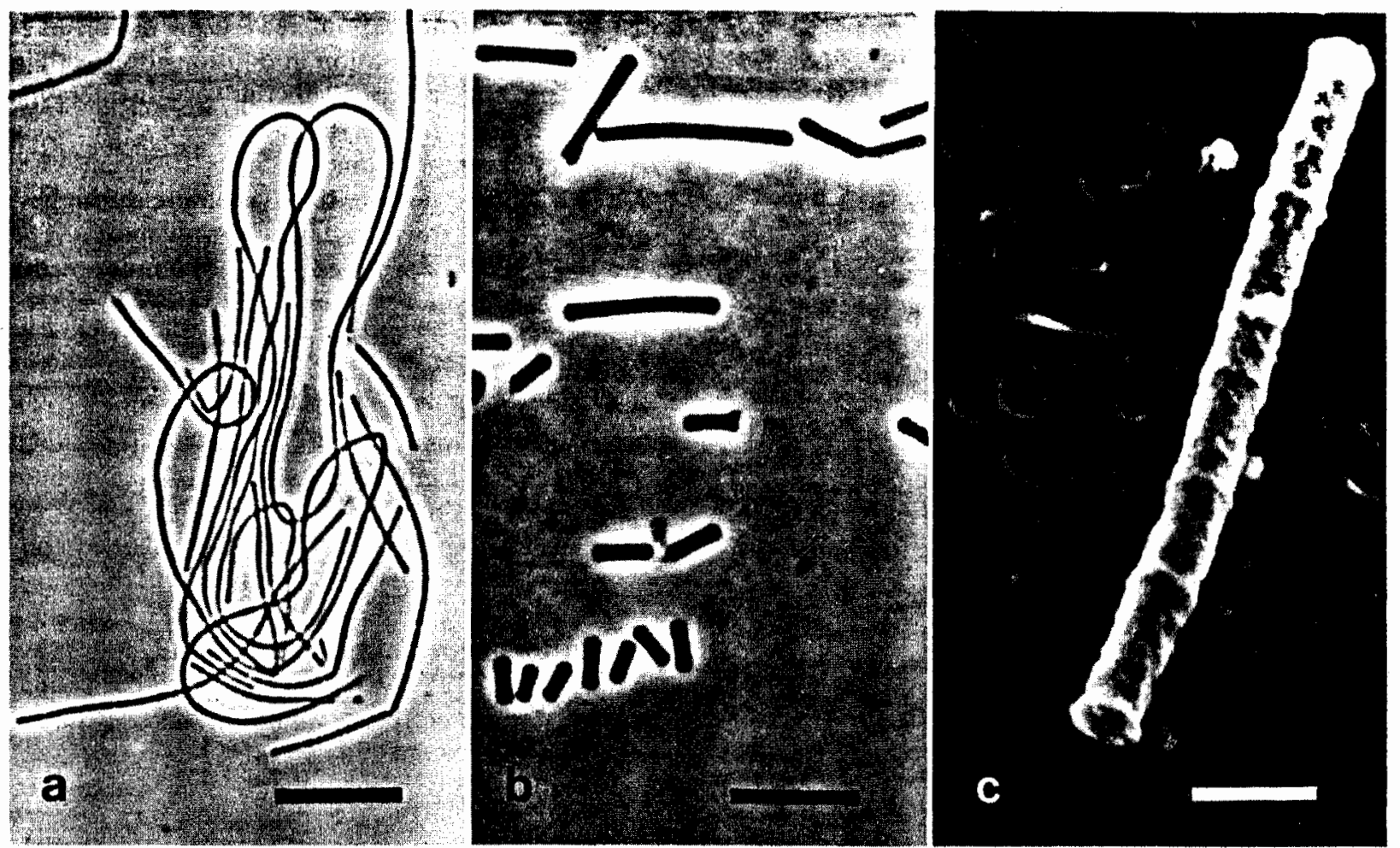

Fig. 1. a Phase contrast photomicrograph of the filaments formed by the "acetate organism", bar indicates $4.7 \mu \mathrm{m}$. b Phase contrast photomicrograph of single cells and short chains; bar indicates $1.9 \mu \mathrm{m}$. e Scanning photomicrograph of filament fragment, bar indicates $1.2 \mu \mathrm{m}$. Micrograph taken by Mrs. D. Metzger, Zürich

The rigid outer layer of the wall appears as a stack of concentric rings of different electron densities (Fig. 2d). The aspect is identical to pictures of $M$. hungatii (Ferry et al., 1974; Zeikus and Bowen, 1975). Cell wall cuts reveal a zonation in the electron density, the innermost zone being the densest (Fig. 2f, g). The outer layer which is common to all cells in a filament represents a sheath-like structure also found in $M$. hungatii. Fig. 3 represents the end of a lysed cell of a negatively stained filament and indicates a concentric structure of the circular septum (folded over into the plain of the preparation) between individual cells.

Fig. $4 a-h$ illustrate a sequence of cell divisions by intracellular septum formation, i.e. a growth of the inner layer of the rigid wall transversally through the cell, closing the lumen like an iris diaphragm and finally pinching off the daughter cells. It seems that in some instances a second transversal wall is formed close to a first one (Fig. 2e, h). Filaments mostly break at such locations.

\section{Acetate Metabolism During Growth}

Figure 5 shows that acetate was stoichiometrically converted into methane during growth of a batch culture. The rate of acetate consumption was the same as the rate of methane formation, with a ratio of almost one mol of methane formed per mol of acetate utilized. Table 1 lists the metabolic endproducts of each carbon of the acetate and shows very clearly that the methyl group of acetate is the methane precursor, and the carboxyl group is converted to $\mathrm{CO}_{2} .1 .3 \%$ to $1.8 \%$ of the acetate is incorporated into biomass. Figure 6 indicates that there is no major discrimination between C-1 and C-2 carbon for incorporation. Besides acetate, carbon dioxide is also incorporated into biomass (see table 2, 3rd and 4th line) and has to be reduced to the oxidation state of organic material. The molar ratio of acetate to carbon dioxide assimilated is approximately 1:9 (Fig. 7). The electrons for $\mathrm{CO}_{2}$ reduction are probably generated in the oxidation of the methyl

Fig. $2 \mathbf{a}-\mathbf{i}$. Thin sections and negative stains of the "acetate organism". $\mathbf{a}$ and $\mathbf{b}$ Parts of the filament with the cells, bars indicate $1.8 \mu \mathrm{m}(\mathrm{a})$ and $3.2 \mu \mathrm{m}$ (b). c Cross section through a cell revealing the rigid wall $(W)$ and the cytoplasmic membrane $(M)$, bar indicates $0.23 \mu \mathrm{m}$. $\mathrm{d}$ Negative stained part of the filament indicating the striation of the cell wall and an ongoing division (arrows), bar indicates $0.25 \mu \mathrm{m}$. $\mathrm{e}$ Formation of a very small daughter cell (arrow) and of two cross walls, bar indicates $0.65 \mu \mathrm{m} . \mathbf{f}, \mathbf{g}$ Fine structure of the rigid wall indicating two layers with high electron density, the inner one going over in the septum (arrow), bars (f) $0.21 \mu \mathrm{m},(\mathrm{g}) 0.1 \mu \mathrm{m}$. h Formation of a second cross wall (arrow), bar indicates $0.36 \mu \mathrm{m}$. i Double layer membrane, bar indicates $0.08 \mu \mathrm{m}$ 

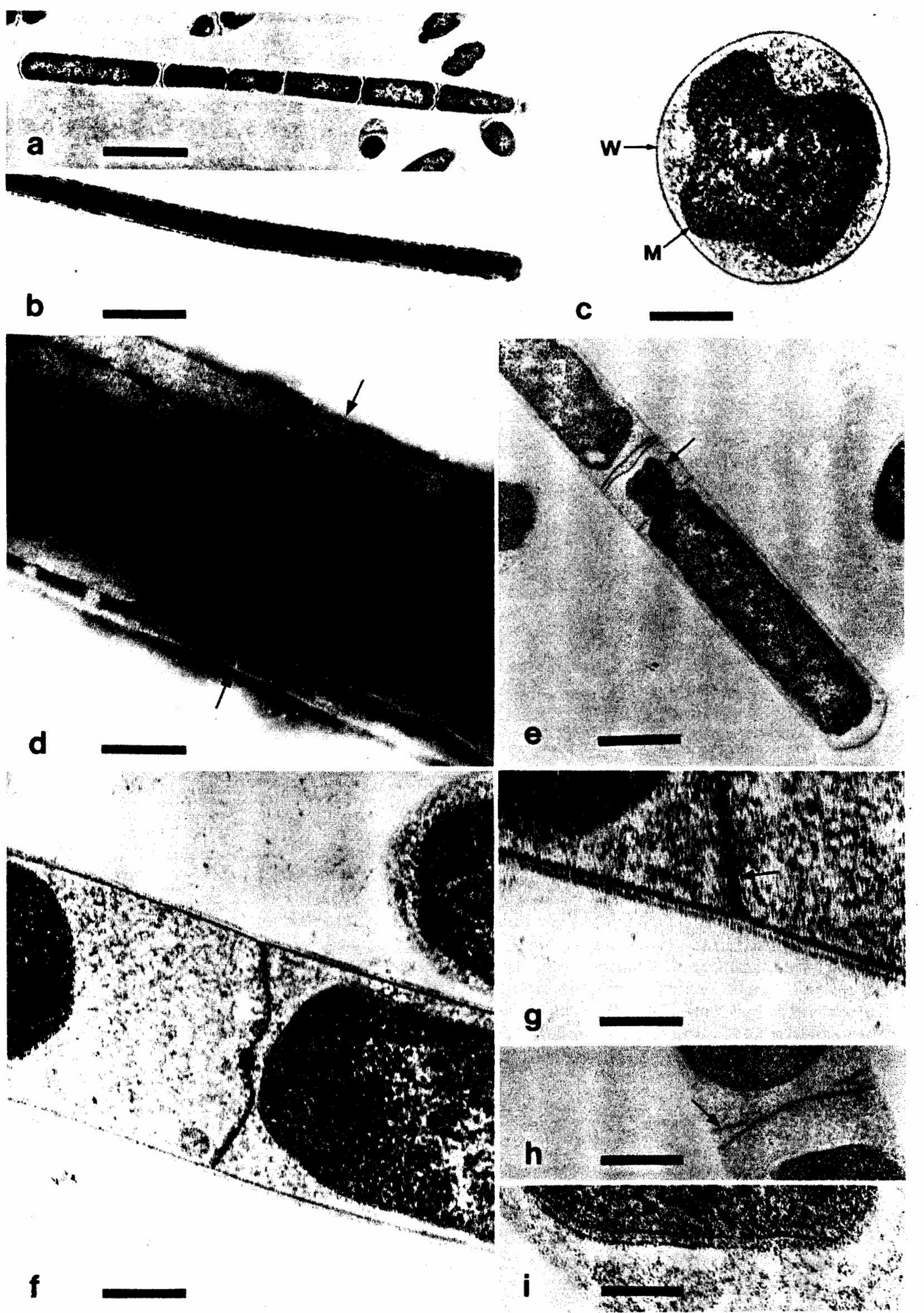

Fig. 2 a $-i$ 


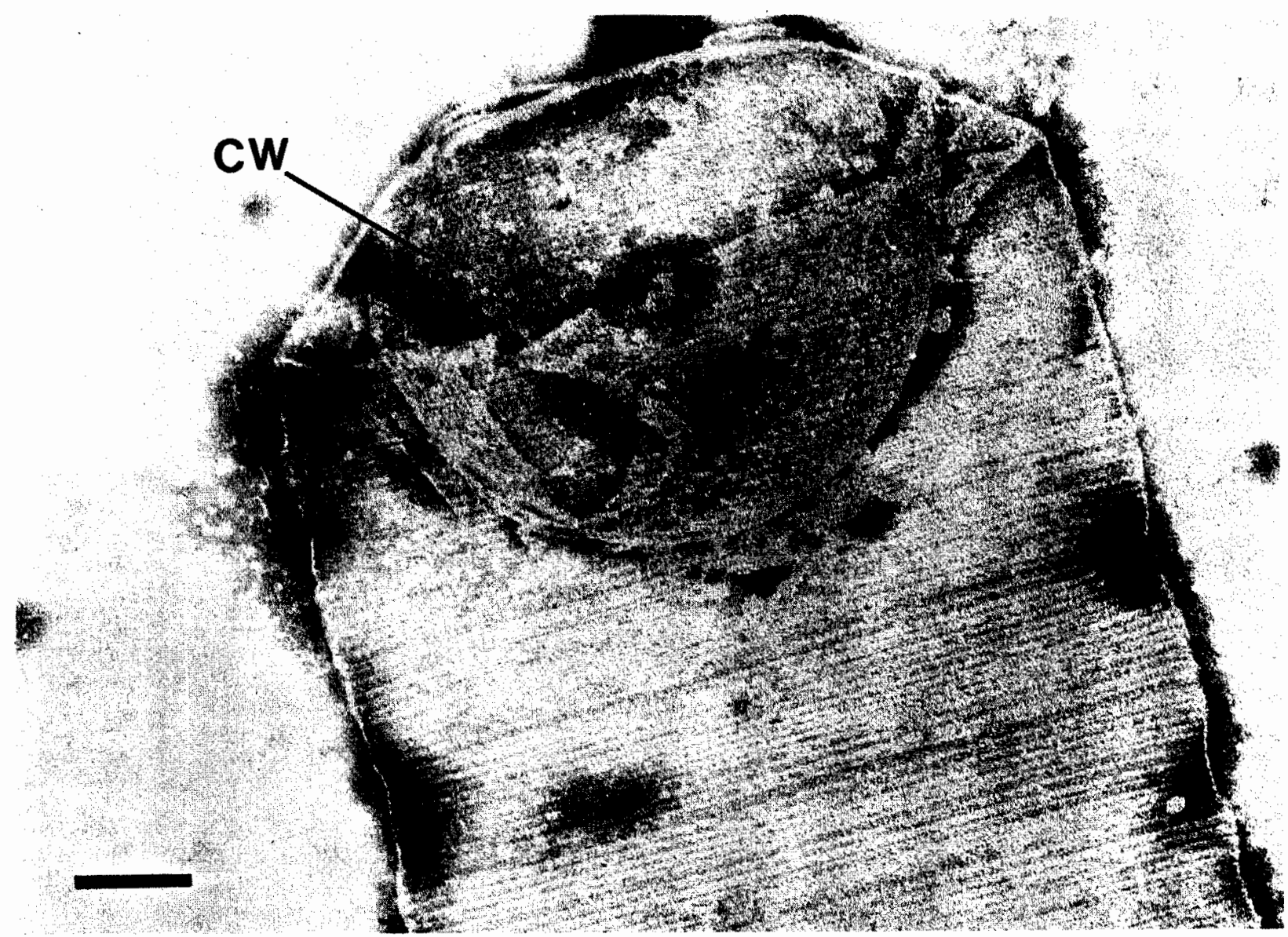

Fig. 3. Negative stain of the cell wall illustrating the laminar striation of the envelope and the concentric circular structure of the cross wall $(C W)$, bar indicates $0.08 \mu \mathrm{m}$

group of acetate (see Table 1 and Fig. 8). The "acetate organism" splits not only acetate but also formate (Table 2, 1st line). It is of historical interest that Popoff in 1873 described the formation of carbon dioxide and hydrogen from calcium formate in anaerobic mud, and already in 1887 , Hoppe-Seyler attributed the cleavage of the formate to the organism which forms methane from acetate. In a later paper (Huser et al., in preparation), we shall discuss the function and role of formate decomposition in more detail.

\section{Assimilation and Metabolism of Other Substrates in Presence of Acetate}

The experiments listed in Table 2 were done in batch cultures in $35-\mathrm{ml}$ serum vials with $20 \mathrm{ml}$ liquid phase. Inoculation occurred with $0.2 \mathrm{ml}$ of a visibly turbid preculture in the same medium. The mineral salts medium contained in all cases $1 \mathrm{mmol}$ acetate per vial. The additional radioactive substrates were injected at the start of the experiment. Methane formation was monitored over the whole incubation period of 28 days. In all vials cells grew well, and at the end of the experiment $85-98 \%$ of the acetate was converted into methane and bicarbonate.

Most surprising is the fact that the acetate organism cannot reduce carbon dioxide with hydrogen (Table 2, last line), a process which was thought to be common to all methanogens. Methanol was not converted to $\mathrm{CH}_{4}$ and $\mathrm{CO}_{2}$. Because of its rather lipophilic character, some methanol might have been dissolved in the lipids of the organism, thus explaining the small activity observed in the biomass (Table 2, 2nd line). The experiments described in Table 1 and 2 were also performed in the presence of hydrogen $\left(\mathrm{p}_{\mathrm{H}_{2}}=1.3 \mathrm{~atm}\right.$ [132 kPa]). In any case, no effect on methane formation was observed. However, hydrogen partially repressed carbon dioxide formation from the methyl group of acetate and from formate decarboxylation. 

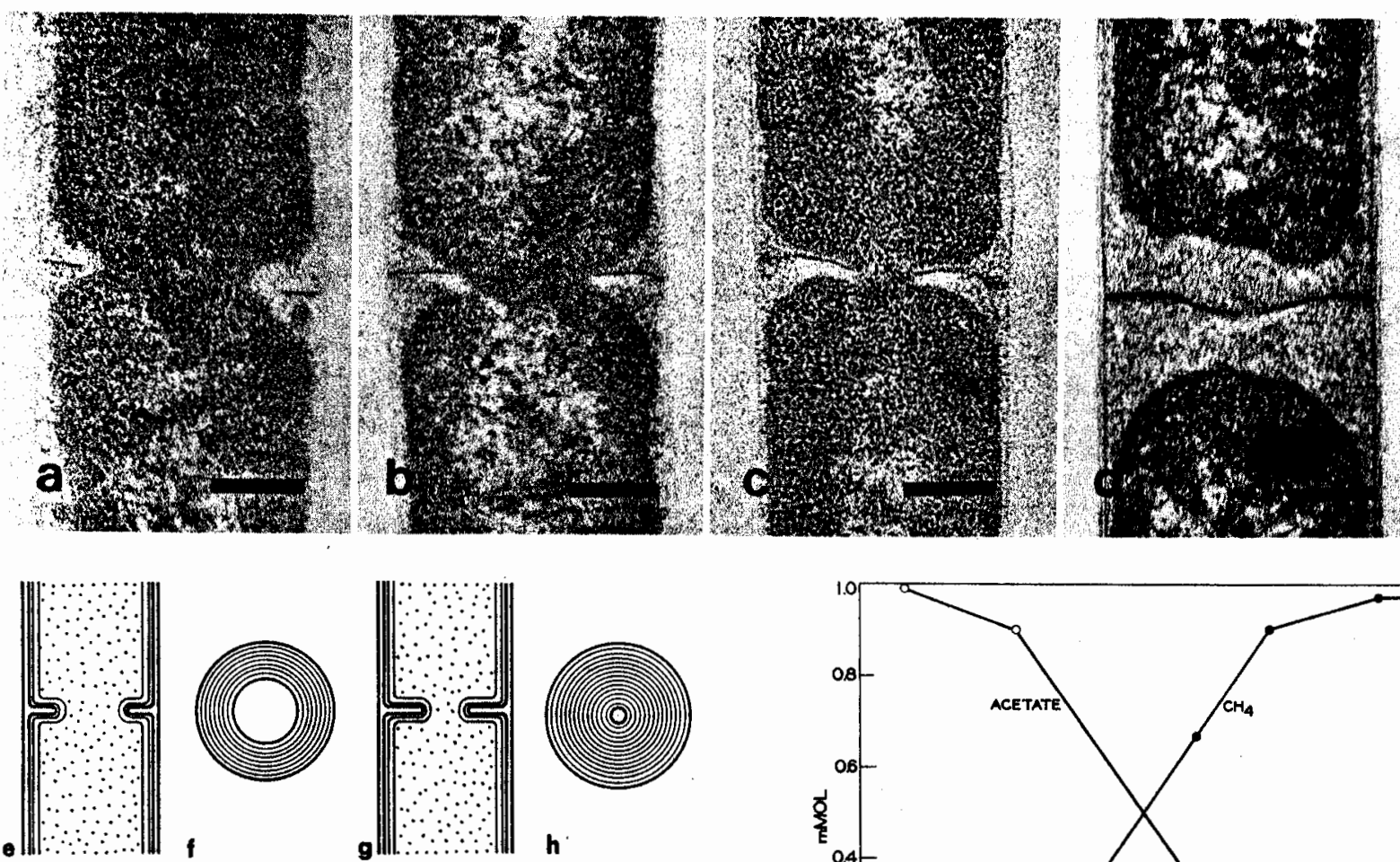

4

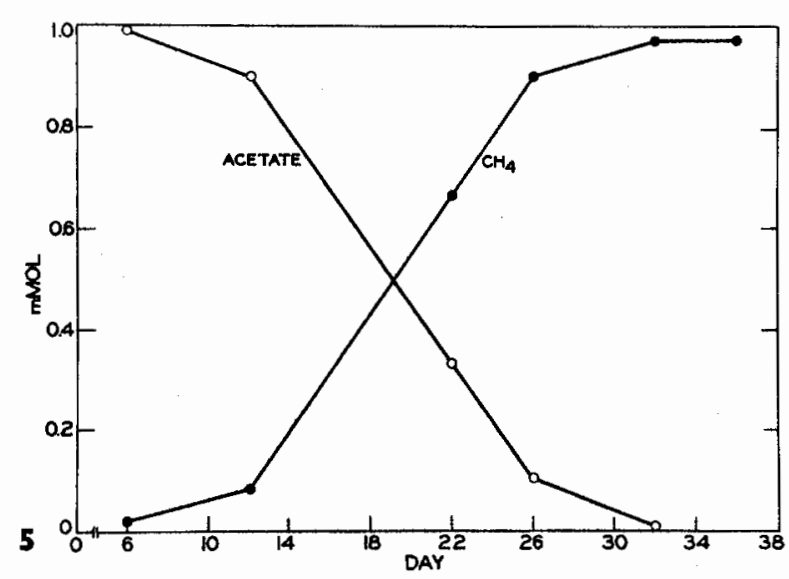

Fig.4. a-d Chronology of a cell division by cross wall formation. $\mathbf{e}, \mathrm{g}$ Scheme of a longitudinal section and $\mathrm{f}$, $\mathrm{h}$ of a view on the septum during cell division. Bars indicate $0.23 \mu \mathrm{m}$

Fig. 5. Relationship between methane production and acetate consumption by a culture of the "acetate organism". Initial pH 7.0 , headspace $85 \%$ $\mathrm{N}_{2}+15 \% \mathrm{CO}_{2}$, temp. $=33^{\circ} \mathrm{C}$

Table 1. Fate of the different carbon atoms of acetate during growth of the "acetate organism"

\begin{tabular}{lllll}
\hline $\begin{array}{l}\text { Labeled } \\
\text { substrate }\end{array}$ & $\begin{array}{l}{ }^{14} \mathrm{CH}_{4} \text { formed } \\
(\mu \mathrm{Ci} / \text { vial })^{\mathrm{a}}\end{array}$ & $\begin{array}{l}14 \mathrm{CO}_{2} \text { formed } \\
(\mu \mathrm{Ci} / \text { vial })\end{array}$ & $\begin{array}{l}\mathrm{C}-14 \text { incorporated } \\
\text { into cell material } \\
(\mu \mathrm{Ci} / \text { vial })\end{array}$ & $\begin{array}{l}\text { Labeled substrate } \\
\text { metabolized } \\
(\%)\end{array}$ \\
\hline${ }^{14} \mathrm{CH}_{3} \mathrm{COO}^{-\mathrm{b}}$ & $\begin{array}{l}2.27 \\
(95 \%)^{\mathrm{d}}\end{array}$ & $\begin{array}{l}0.074 \\
(3.1 \%)\end{array}$ & $\begin{array}{l}0.045 \\
(1.8 \%)\end{array}$ \\
$\mathrm{CH}_{3}{ }^{14} \mathrm{COO}^{-\mathrm{c}}$ & $\begin{array}{l}0.017 \\
(0.04 \%\end{array}$ & $\begin{array}{l}3.88 \\
(98 \%)\end{array}$ & $(1.3 \%)$ & 0.051 \\
\end{tabular}

a In a 35 -ml serum vial with $20 \mathrm{ml}$ liquid phase, headspace $85 \% \mathrm{~N}_{2}, 15 \% \mathrm{CO}_{2}$

b $\quad 0.66 \mathrm{mmol}$ sodium $\left[2{ }^{14} \mathrm{C}\right]$ acetate, specific activity $3.61 \mu \mathrm{Ci} / \mathrm{mmol}$

c $\quad 0.70 \mathrm{mmol}$ sodium $\left[1-{ }^{14} \mathrm{C}\right]$ acetate, specific activity $5.64 \mu \mathrm{Ci} / \mathrm{mmol}$

d $\%$ of the total added labeled substrate

* not significant

\section{Determination of the Coenzyme $M$ Level}

2-Bromoethanesulfonic acid, a coenzyme $M$ analog, is a potent inhibitor of methane production (Gunsalus et al., 1976). At a concentration of $5 \cdot 10^{-7} \mathrm{M}$ $\mathrm{BrCh}_{2} \mathrm{CH}_{2} \mathrm{SO}_{3}^{-}$, methane formation by our acetatecleaving organism attained only half of its normal rate (Zehnder and Brock, 1979). This finding suggested the 

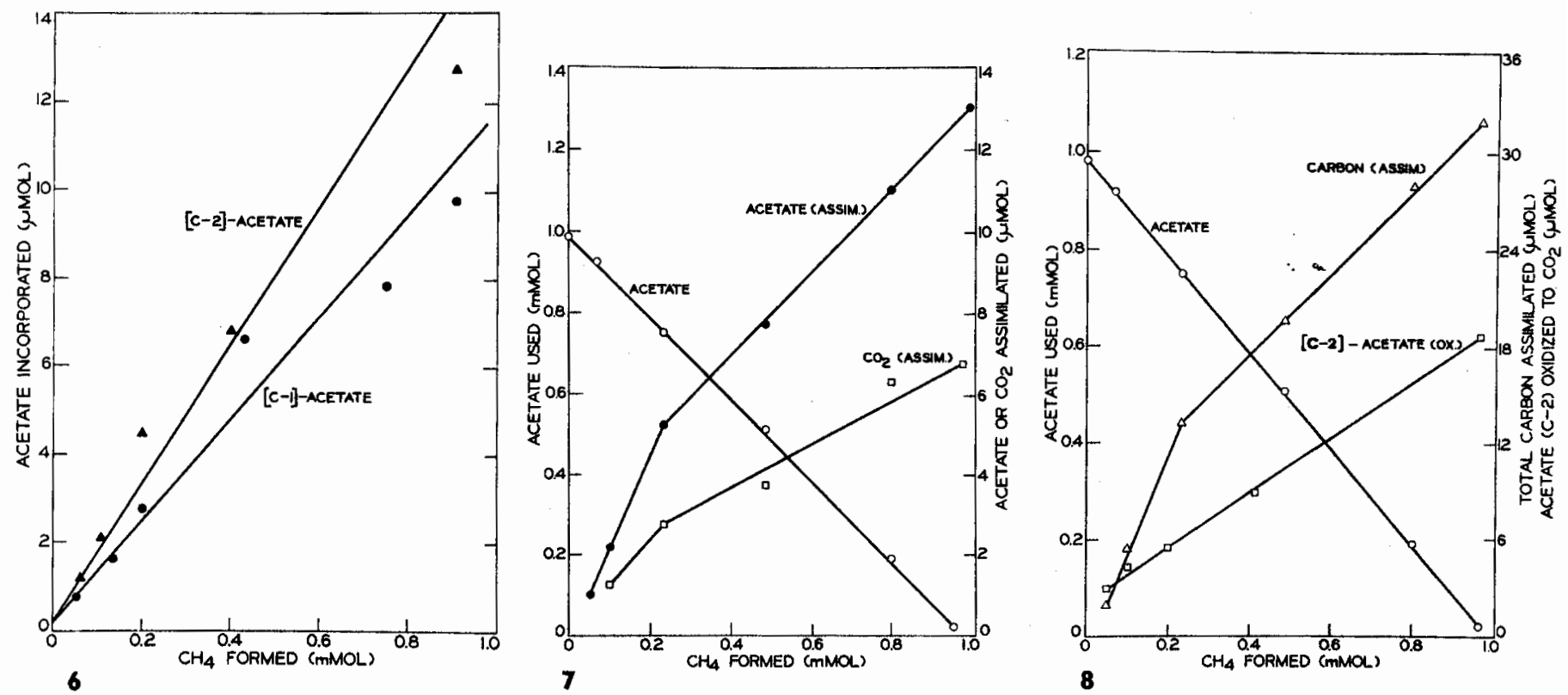

Fig. 6. Incorporation of the methyl carbon and the carboxyl carbon of acetate as a function of methane production. The relative amounts incorporated were calculated from tracer experiments with acetate labeled in C-1 or C-2 position. Lines were drawn using the least squares method

Fig. 7. Acetate consumption and acetate and carbon dioxide assimilation in relation to methane production in the culture

Fig. 8. Acetate consumption, total carbon-assimilated (calculated from the values in Fig. 7) and carbon dioxide formation by oxidation of the methyl group of acetate in relation to methane production

Table 2. Use of various methanogenic substrates for methane formation and cell carbon synthesis by the "acetate organism" a

\begin{tabular}{|c|c|c|c|c|c|c|}
\hline $\begin{array}{l}\text { Labeled } \\
\text { substrate }\end{array}$ & $\begin{array}{l}\text { Label } \\
\text { added } \\
(\mu \mathrm{Ci})\end{array}$ & $\begin{array}{l}{ }^{14} \mathrm{CH}_{4} \\
\text { formed } \\
(\mu \mathrm{Ci} / \text { vial })^{b}\end{array}$ & $\begin{array}{l}{ }^{14} \mathrm{CO}_{2} \\
\text { formed } \\
(\mu \mathrm{Ci} / \text { vial })\end{array}$ & $\begin{array}{l}\mathrm{C}-14 \text { incor- } \\
\text { porated into } \\
\text { cell material } \\
(\mu \mathrm{Ci} / \mathrm{vial})\end{array}$ & $\begin{array}{l}\mathrm{C} \text { incorpor- } \\
\text { ated into } \\
\text { cell material } \\
(\mu \mathrm{mol})\end{array}$ & $\begin{array}{l}\text { Labeled } \\
\text { substrate } \\
\text { metabolized } \\
(\%)^{c}\end{array}$ \\
\hline $\mathrm{H}^{14} \mathrm{COO}^{-e}$ & 12.5 & $<0.001$ & 11.96 & 0.002 & 0.07 & $95.7^{\mathrm{g}}$ \\
\hline${ }^{14} \mathrm{CH}_{3} \mathrm{OH}^{\mathrm{f}}$ & 9.4 & $<0.001$ & $<0.001$ & 0.002 & 0.1 & 0.02 \\
\hline${ }^{14} \mathrm{CO}_{2}{ }^{\mathrm{d}}$ & 10.0 & $<0.001$ & - & 0.028 & 5.7 & 0.28 \\
\hline${ }^{14} \mathrm{CO}_{2}{ }^{\mathrm{h}}$ & 10.0 & $<0.001$ & - & 0.036 & 7.4 & 0.36 \\
\hline
\end{tabular}

- In a medium already containing $50 \mathrm{mM}$ unlabeled sodium acetate. The values represent means of duplicates

b In a $35-\mathrm{ml}$ serum vial with $20 \mathrm{ml}$ liquid phase, headspace $85 \% \mathrm{~N}_{2}, 15 \% \mathrm{CO}_{2}$

c $\%$ of the total added labeled substrate

d The specific activity of $\mathrm{CO}_{2}$ is continuously diluted by the additional production of bicarbonate from acetate decarboxylation. At the moment of measurement, the specific activity was $4.8 \mu \mathrm{Ci} / \mathrm{mmol}$

e Specific activity $28.15 \mu \mathrm{Ci} / \mathrm{mmol}$

I Specific activity $15.04 \mu \mathrm{Ci} / \mathrm{mmol}$

8 Besides ${ }^{14} \mathrm{CO}_{2}$, hydrogen was found in the atmosphere

h The headspace in the vial was $80 \% \mathrm{H}_{2}, 20 \% \mathrm{CO}_{2}$

presence of coenzyme $\mathrm{M}$ in the cells. In bioassays using the coenzyme-M-requiring Methanobacterium ruminantium strain M1 (Balch and Wolfe, 1976), we indeed found levels of $0.35 \mathrm{nmol}$ coenzyme $\mathrm{M}$ per $\mathrm{mg}$ of dry cells.

\section{Determination of $F_{420}$ Fluorescence}

The flavin analogue $\mathrm{F}_{420}$ occurs exclusively in methanogenic bacteria and is involved in the electron transport system (Eirich et al., 1978). The oxidized $F_{420}$ 
fluorescence under UV light (Edwards and McBride, 1975). Hence, methane bacteria can easily be detected under the microscope (Doddema and Vogels, 1978). We examined all the known methanogens under the fluorescence microscope and found that they fluorescence when cultivated on $\mathrm{H}_{2}$ and $\mathrm{CO}_{2}$ or formate or methanol (M. barkeri). Cultures (Methanosarcina strain 227 [Mah et al., 1978], $M$. barkeri, an acetate enrichment from Lake Mendota containing no sarcinas, and our organism) grown on acetate, however, showed no obvious fluorescence, and we have never been able to detect any single cell with this method. The sarcinas and the acetate enrichment from Lake Mendota regained their bright fluorescence after they were switched back for $12 \mathrm{~h}$ on methanol or $\mathrm{H}_{2}$ and $\mathrm{CO}_{2}$.

The analysis of cell-extracts from the "acetate organism" for a $\mathrm{F}_{420}$-dependent NADP-linked hydrogenase showed $\mathrm{F}_{420}$ activity. The amount obtained in one single assay with all cells available was $0.55 \mu \mathrm{g}$ $\mathrm{F}_{420}$ per $\mathrm{mg}$ protein. This is a very low amount compared to 2.5 to $82 \mu \mathrm{g} \mathrm{F}_{420}$ per $\mathrm{mg}$ protein of methanogens grown on $\mathrm{H}_{2}$ and $\mathrm{CO}_{2}$ (L. D. Eirich, $\mathrm{Ph}$. D. thesis, University of Illinois at Urbana-Champaign, 1978) and might explain why the "acetate organism" cannot be detected under the fluorescence microscope.

\section{Discussion}

The general appearance of the "acetate organism" is of a straight rod with flat ends. The gram stain is negative. Unshaken cultures show multicellular filaments rather than unicellular rods. Because of its ability to form long filaments, this organism should be called Methanothrix rather than Methanobacterium. However, more information is needed, such as Guanosin plus Cytosin content, lipid composition, cell wall structure and nucleotide sequence of the $16 \mathrm{~S}$ ribosomal RNA, before this organism can be definitively named and classified. For a successful 16S RNA determination, the cells have to double at least twice in a medium containing ${ }^{32} \mathrm{PO}_{4}^{3-}$ (C. R. Woese, personal communication). However, the long generation time, which is at its best. 9 days, represents together with the short half life of ${ }^{32} \mathrm{P}$ a severe obstacle to characterize the 16S RNA in this way. Recent work has shown that the lipids of the "acetate organism" consists of all phytanylethers, similar to Methanococcus (T. Langworthy, personal communication).

The organism shares apparently the unique topography of the cell wall with Methanospirillum hungatii (Zeikus and Bowen, 1975).

The principle energy substrate of the "acetate organism" is acetate. Hydrogen, the common substrate for all other known methane producers, is not utilized for methane formation. These findings raise the question of how an organism can generate enough energy for growth from the simple splitting of acetate. Already in 1887, Hoppe-Seyler doubted whether an organism might benefit from such a process. Chemically, the acetate cleavage is a decarboxylation. Pine and Barker (1956) showed that the three protons of the methyl group remained intact, and the fourth proton was supplied by water. This decarboxylation can best be considered as an intramolecular redox process:

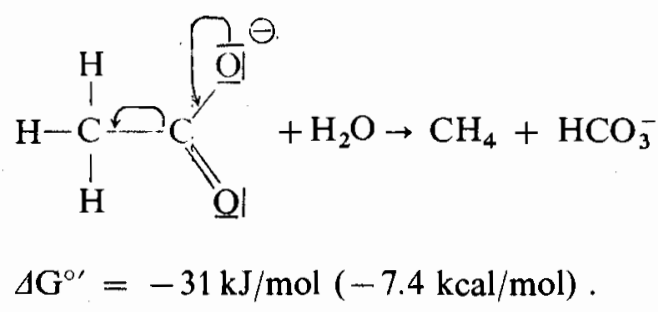

ATP formation by substrate-level phosphorylation is unlikely to occur in this reaction. The other possibility of producing ATP is through electron transport. Based on the chemiosmotic theory of Mitchell (1966), the thermodynamic problem of the insufficient free energy of this reaction for ATP synthesis bound to a strict stoichiometry could indeed be overcome. Mountfort (1978) recently published experimental evidence suggesting that in methanogenesis (he worked with Methanosarcina barkeri) a proton translocation mechanism might be responsible for ATP formation. Interestingly enough, some of his assays with DNP inhibition are confirmed by earlier observations with Methanobacterium strain AZ (Wellinger, thesis, 1977). The pursuit of investigations on the line of Mountfort are obviously of fundamental interest for the understanding of the ATP formation in the "acetate organism".

Coenzyme $M$ is detected exclusively in methanogens (Balch and Wolfe, 1979). The presence of this cofactor in our organism clearly relates it to the group of methane bacteria. However, compared with the other methanogenic microbes, the coenzyme $M$ concentration in the "acetate organism" is one of the lowest ever found (Balch and Wolfe, 1979).

We found a substrate affinity of the "acetate organism" of $K_{\mathrm{s}} \approx 0.46 \mathrm{mM}$. This is a high affinity as compared to Methanosarcina strain $227\left(K_{\mathrm{s}}\right.$ appr. $5 \mathrm{mM}$, Smith and Mah, 1978). Ecologically, this might allow the "acetate organism" to compete with the more efficient and faster growing sarcina. In fact, we were never able to isolate a sarcina from the digested sludge from Opfikon near Zürich which contained at most 
$0.5 \mathrm{mmol}$ per liter of acetate (Kaspar and Wuhrmann, 1978). In sludges with high acetate concentrations, however, the sarcina-type cells are predominant (S. H. Zinder, personal communication). This indicates that under natural conditions, the fastest growing and most efficient organism is not necessarily the ecologically most important one.

Acknowledgements. We are indebted to Dr. R. S. Wolfe for giving B. $\mathrm{H}$. the opportunity to work in his laboratory and his co-workers for their assistance in the determination of coenzyme $M$ and $F_{420}$. We thank Dr. J. Pate for many useful suggestions, Mrs. D. Metzger (Zürich) for the scanning electron micrograph, and Rick Heinzen (Madison) for his excellent technical assistance for the electron microscopy work. Financial support was provided by the College of Agricultural and Life Sciences and the Department of Energy (Contract EY-76-S-02-2161). A. J. B. Z. was supported in part by a postdoctoral fellowship from the Swiss National Science Foundation.

\section{References}

Balch, W. E., Wolfe, R. S.: New approach to cultivation of methanogenic bacteria: 2-mercaptoethanesulfonic acid (HSCoM)-dependent growth of Methanobacterium ruminantium in a pressurized atmosphere. Appl. Environ. Microbiol. 32, 781 - 791 (1976)

Balch, W. E., Wolfe, R. S.: Specificity and biological distribution of coenzyme M (2-mercaptoethanesulfonic acid). J. Bacteriol. 137, $256-263$ (1979)

Barker, H. A.: Studies upon the methane-producing bacteria. Arch. Mikrobiol. 7, 420-438 (1936)

Bryant, M. P.: Methane-producing bacteria. In : Bergey's manual of determinative bacteriology, 8th ed. (R. E. Buchanan, N. E. Gibbons, eds.), pp. 472-477. Baltimore: Williams and Wilkins 1974

Buswell, A. M., Neave, S. L.: Laboratory studies of sludge digestion. Illinois State Water Survey, Bulletin No. 30, Urbana, Ill. (1930)

Doddema, H. J., Vogels, G. D. : Improved identification of methanogenic bacteria by fluorescence microscopy. Appl. Environ. Microbiol. 36, 752- 754 (1978)

Edwards, T., McBride, B. C.: New method for the isolation and identification of methanogenic bacteria. Appl. Microbiol. 29, $540-545$ (1975)

Eirich, L. D. : The structure of coenzyme $\mathrm{F}_{420}$, a novel electron carrier isolated from Methanobacterium strain M.o.H. Ph. D. thesis, University of Illinois at Urbana-Champaign (1978)

Eirich, L. D., Vogels, G. D., Wolfe, R. S.: Proposed structure for coenzyme $\mathrm{F}_{420}$ from Methanobacterium. Biochemistry 17, $4583-4593$ (1978)

Ferry, J. G., Smith, P. H., Wolfe, R. S.: Methanospirilum, a new genus of methanogenic bacteria and characterization of Methanospirillum hungatii sp. nov. Int. J. Syst. Bacteriol. 24, $465-469$ (1974)

Ferry, J. G., Wolfe, R. S.: Anaerobic degradation of benzoate to methane by a microbial consortium. Arch. Microbiol. 107, $33-$ 40 (1976)

Groenewege, J.: Bakteriologische Untersuchungen über biologische Reinigung. Med. Burg. Geneesk. Dienst, Deel 1, 66-125 (1920)

Gunsalus, R., Eirich, L. D., Romesser, J., Balch, W., Shapiro, S., Wolfe, R. S.: Methyl transfer and methane formation. In: Microbial production and utilization of gases $\left(\mathrm{H}_{2}, \mathrm{CH}_{4}, \mathrm{CO}\right)(\mathrm{H}$. G. Schlegel, G. Gottschalk, D. Pfennig, eds.), pp. 191-197. Göttingen: Goltze (1976)
Gunsalus, R. P., Wolfe, R. S.: Stimulation of $\mathrm{CO}_{2}$ reduction to methane by methyl-coenzyme $\mathrm{M}$ in extracts of Methanobacterium. Biochem. Biophys. Res. Commun. 76, 790-795 (1977)

Hoppe-Scyler, F.: Über die Processc der Gährungen und ihrc Bezichung zum Leben der Organismen. Pflüger's Arch. f. ges. Physiol. 12, 1-- 17 (1876)

Hoppe-Scyler, F.: Die Methangährung der Essigsäurc. HoppeSeyler's Z. Physiol. Chem. 11, 561-568 (1887)

Horridge, G. A., Tamm, S. L.: Critical point drying for scanning electron microscopic study of ciliary motion. Science 163, 817818 (1969)

Kaspar, H. F., Wuhrmann, K.: Kinetic parameters and relative turnovers of some important catabolic reactions in digesting sludge. Appl. Environ. Microbiol. 36, 1 - 7 (1978)

Lowry, O. H., Rosebrough, N. J., Farr, A. L., Randall, R. J. : Protein measurement with the Folin phenol reagent. J. Biol. Chem. 193, $265-275(1951)$

Mah, R. A., Smith, M. R., Baresi, L.: Studies on an acetatefermenting strain of Methanosarcina. Appl. Environ. Microbiol 35, 1174-1184 (1978)

Mitchell, P.: Chemiosmotic coupling in oxidative and photosynthetic phosphorylation. Biol. Rev. Cambridge Philos. Soc. 41, 445502 (1966)

Mountfort, D. O.: Evidence for ATP synthesis driven by a proton gradient in Methanosarcina barkeri. Biochem. Biophys. Res. Comm. 85, 1346-1352 (1978)

Mylroie, R. L., Hungate, R. E. : Experiments on the methane bacteria in sludge. Can. J. Microbiol. 1, 55-64 (1954)

Pine, M. J., Barker, H. A.: Studies on the methane fermentation. XII The pathway of hydrogen in the acetate fermentation. $J$. Bacteriol. 71, 644-648 (1956)

Popoff, L.: Über die Sumpfgasgährung. Pflüger's Arch. f. ges. Physiol. 10, 113-146 (1873)

Pretorius, W. A.: The effect of formate on the growth of acetate utilizing methanogenic bacteria. Water Res. 6, 1213-1217 (1972)

Reynolds, $\mathrm{E}$ : : The use of lead citrate at high $\mathrm{pH}$ as an electron opaque stain in electron microscopy. J. Cell Biol. 17, 208-212 (1963)

Schnellen, Ch. G. T, P.: Onderzoekingen over de Methaangistring. Dissertation. Technische Hoogeschool Delft. Rotterdam: De Maasstad 1947

Smit, J.: Die Gärungssarcinen. Eine Monographie. Pflanzenforschung 14, 1-59 (1930)

Smith, M. R., Mah, R. A.: Growth and methanogenesis by Methanosarcina strain 227 on acetate and methanol. Appl. Environ. Microbiol. 36, 870-879 (1978)

Söhngen, N. L.: Sur le rôle du méthane dans la vie organique. Rec. trav. chim. 29, 238-274 (1910)

Spurr, A. R.: A low viscosity epoxy resin embedding medium for electron microscopy. J. Ultrastruct. Res. 26, $31-43$ (1969)

Stadtman, T. C., Barker, H. A.: Studies on the methane fermentation. IX. The origin of methane in the acetate and methanol fermentations by methanosarcina. J. Bacteriol. 61, 81-86 (1951)

Tzeng, S. F., Wolfe, R. S., Bryant, M. P.: Factor 420-dependent pyridine nucleotide-linked hydrogenase system of Methanobacterium ruminantium. J. Bacteriol. 121, 184-191 (1975)

van den Berg, L., Patel, G. B., Clark, D. S., Lentz, C. P.: Factors affecting rate of methane formation from acetic acid by enriched methanogenic cultures. Can. J. Microbiol. 22, 1312-1319(1976)

Wellinger, A.: Untersuchungen über den Stoffwechsel des Methanbakteriums Stamm AZ. Ph. D. thesis ETH No. 5878. Zürich: Juris Druck and Verlag 1977

Wolin, E. A., Wolin, M. J., Wolfe, R. S. : Formation of methane by bacterial extracts. J. Biol. Chem. 238, 2882-2886 (1963)

Zehnder, A. J. B., Wuhrmann, K.: Physiology of a Methanobacterium strain AZ. Arch. Microbiol. 111, 199-205 (1977) 
Zehnder, A. J. B., Brock, T. D.: Methane formation and methanc oxidation by methanogenic bacteria. J. Bacteriol. 137, 420--432 (1979)

Zehnder, A. J. B., Huser, B., Brock, T. D.: Mcasuring radioactive methane with liquid scintillation counter. Appl. Environ. Microbiol. 37, 897-899(1979)

Zeikus. J. G., Bowen, V. G.: Fine structure of Methanospirilhum hingatii. J. Bacteriol. 121, 373-380 (1975)
Zeikus, J. G., Winfrey, M. R.: Temperature limitation of methanogenesis in aquatic sediments. Appl. Environ. Microbiol. 31, 991.07 (1976)

Zhilina, T. N.: The fine structure of Methanosarcina. Mikrobiologiya $40,674-680(1971)$

Received May 31, 1979 